\title{
Verification of 3D-printed universal smartphone retinal imaging adapter against conventional fundus camera imaging for diabetic retinopathy screening
}

\author{
Yuen Keat Gan, Amir Samsudin
}

Department of Ophthalmology, Faculty of Medicine, University of Malaya, Kuala Lumpur, Malaysia

\section{Abstract}

Introduction: Screening for diabetic retinopathy (DR) is critical in preventing visual loss. However, current tools are expensive, bulky and sensitive, thus limiting screening coverage, especially in developing areas such as the interior of Borneo. Smartphone-assisted devices may provide an alternative and this study seeks to determine the level of agreement between a smartphone retinal imaging adapter (SRIA) against conventional ones.

Materials and methods: This was a cross-sectional study with Institutional Review Board approval from the Medical Ethics Board of University of Malaya Medical Centre. A total of 284 eyes from 142 patients included underwent retinal imaging using a conventional fundus camera and the SRIA. The images were graded according to Early Treatment of Diabetic Retinopathy Study (ETDRS) classification. Agreement between both modalities was calculated using Cohen's Kappa statistics.

Results: The Kappa agreement between SRIA and conventional fundus imaging in grading individual ETDRS stages stood at $0.648(p<0.001)$, achieving up to 0.752 ( $p<$ 0.001 ) when differentiating between no DR, non-proliferative $D R$, and proliferative DR. Conclusion: DR grading SRIA and conventional fundus camera imaging were comparable. SRIA can be useful in eye screenings but still needs improvement.

Correspondence: Dr. Yuen Keat Gan, Department of Ophthalmology, Faculty of Medicine, 50603 Kuala Lumpur, Malaysia.

E-mail: fruitdoves@yahoo.com 
Keywords: diabetic retinopathy, fundus camera, smartphone retinal imaging

\section{Pengesahan pengesanan retinopati diabetes menggunakan adaptor perakam imej retina $3 \mathrm{D}$ pada telefon pintar universal berbanding dengan pengimejan kamera fundus secara konvensional}

\section{Abstrak}

Pendahuluan: Pemeriksaan retinopati diabetes (DR) sangat penting untuk mencegah kehilangan penglihatan dan kebutaan. Walau bagaimanapun, alat yang disedia ada sekarang adalah mahal, bersaiz besar dan sensitif, sehingga membatasi liputan penyaringan, terutama di kawasan yang sedang membangun, seperti pedalaman Borneo. Alat peranti yang dibantu telefon pintar mungkin memberikan alternative. Kajian ini bertujuan untuk menentukan tahap persetujuan imej antara adaptor perakam imej retina 3D pada telefon pintar universal (SRIA) berbanding pengimejan kamera fundus secara konvensional.

Bahan dan kaedah: Ini adalah kajian keratan rentas yang mendapat kelulusan panel kajian institusi dari panel etika perubatan Pusat Perubatan Universiti Malaya. Sebanyak 284 mata dari 142 pesakit diabetes telah menjalani pengimejan retina menggunakan kamera fundus konvensional dan SRIA. Imej telah dinilai mengikut klasifikasi Kajian Rawatan Awal Diabetik Retinopati (ETDRS). Persetujuan antara kedua-dua kaedah pengimejan dihitung menggunakan statistik Kappa Cohen.

Keputusan: Persetujuan Kappa dalam pengimejan retina menggunakan SRIA dan kamera fundus konvensional dalam menilai tahap ETDRS individu terlibat berada pada tahap $0.648(p<0.001)$, sehingga $0.752(p<0.001)$ bagi mengesan ketiadaan DR, DR tidak proliferatif, dan DR proliferatif.

Kesimpulan: Penggredan imej DR di antara kaedah SRIA dan kamera fundus konvensional adalah setanding. SRIA berpotensi sebagai peralatan bagi pengesanan penyakit mata tetapi masih perlu menjalani penambahbaikan lagi.

Kata kunci: kamera fundus, pengimejan retina telefon pintar, retinopati diabetes 


\section{Introduction}

Screening and detection of diabetic retinopathy (DR) is a vital first step to enable early intervention and arrest progression of the blinding complication of diabetes mellitus. In many countries, screening of DR is performed using fundus photography by trained technicians, following which images are read by ophthalmologists who then plan subsequent actions. The gold standard initially employed was the 7-field Early Treatment of Diabetic Retinopathy (ETDRS) fundus photography; however, this was time-consuming, tedious and uncomfortable for many patients. Several studies compared the use of 1-field, 2-field and 3-field fundus photography against the 7-field ETDRS fundus photography. ${ }^{1-9}$ As the methods with fewer photographs were found to be a good compromise with reasonable sensitivity and patient comfort, 2or 3-field fundus photography are now commonly used for screening. ${ }^{4,10}$ However, although quick and non-invasive, the equipment needed is still expensive, bulky, sensitive, and confined mainly to larger centres. As a result, there is still a barrier to recommended eye examinations where large numbers of diabetic patients default their follow-up appointments in view of geographical difficulty and cost of attending screening centres.

We believe there is a need for a device that is low cost, ultra-portable, and highly adaptable so that screening may be brought to the community. Several groups have introduced different designs of portable fundus cameras with considerable results; however, these devices are still relatively expensive and are largely fragile. ${ }^{11,12}$ In the ubiquitous smartphone era, other groups have tested ways for easing the screening of DR using smartphones. ${ }^{13,14}$ The use of smartphones and condensing lenses for fundus photography has been described by Haddock et al.,${ }^{14}$ Dyaberi et al., ${ }^{15}$ and Russo et al. ${ }^{16}$ Rajalakshmi et al. applied their devices for DR screening and found favourable results. ${ }^{17}$ However, their devices were still commercially produced and relatively costly. 3D-printed lens adapter designs have now been introduced, ${ }^{13,18}$ and have the advantages of being relatively low cost and ultra-portable. In this study, we sought to validate one of these 3D-printed lens adapters as described by Hong et al. ${ }^{19}$ for detecting and grading DR.

\section{Materials and methods}

This was an observational, cross-sectional study. It adhered to the Declaration of Helsinki and Good Clinical Practice guidelines. Institutional Review Board approval was obtained from the Medical Ethics Board of the University Malaya Medical Centre (UMMC). Informed consent was taken from each patient prior to being recruited into the study.

Male and female, type 1 and type 2 diabetes mellitus patients undergoing eye screening at the Ophthalmology clinic of the UMMC eye clinic were approached. 
The inclusion criteria were: between 18 and 90 years old, any stage of diabetic retinopathy from no DR to proliferative diabetic retinopathy (PDR), and physically and cognitively fit to undergo both smartphone retinal imaging adapter (SRIA) and conventional fundus camera imaging. The exclusion criteria were: history of ocular morbidities (corneal disorders, macular disorders, glaucoma and intraocular inflammation), contraindication to mydriatic agents, poorly dilating pupils (less than $6 \mathrm{~mm}$ ), and media opacities (corneal scars, dense cataracts, dense asteroid hyalosis, etc.) precluding fundus examination. All patients underwent a complete eye examination with slit-lamp biomicroscopy. This was followed by fundus photography using the SRIA which attached a 20 D objective lens to an iPhone 6 smartphone (with built-in 8-megapixel camera) and a conventional fundus camera (Topcon TRC-50DX - Type IA; Tokyo, Japan).

The SRIA was made using 3D-printed parts. The parts were made from acrylonitrile butadiene styrene of approximately three layers per $\mathrm{mm}$ and $1 \mathrm{~mm}$ minimum wall thickness. Nuts and bolts to hold the various pieces in place were sourced from a local hardware shop. Design specifications of the tool were selected from stereolithography files provided open source by $\mathrm{Hong}^{18}$ and printing was done at a local 3D printing shop. The cost of producing the device depended on the weight (per gram) and type of material used. The approximate cost of 3D printing our SRIA was 25 USD. As for the optics, a 20 D condensing lens (Volk Optical Inc.; Mentor, Ohio, USA) was attached to the SRIA. The combined assembly was then attached to the iPhone 6 smartphone that had a built-in 8-megapixel iSight camera with 1.5 $\mu$ pixel size and continuous flash capacity. The device would utilise the flash of the smartphone for co-axial illumination of the retina. It had a $40^{\circ}$ field of view and 33 $\mathrm{mm}$ working distance. The resolution of the image would depend on the make of the smartphone. The device was fitted onto the smartphone, as shown in Figure 1. The native camera application which has auto-focus and continuous illumination capabilities was utilised. The touch screen interface of the smartphone controlled all image-acquiring work.

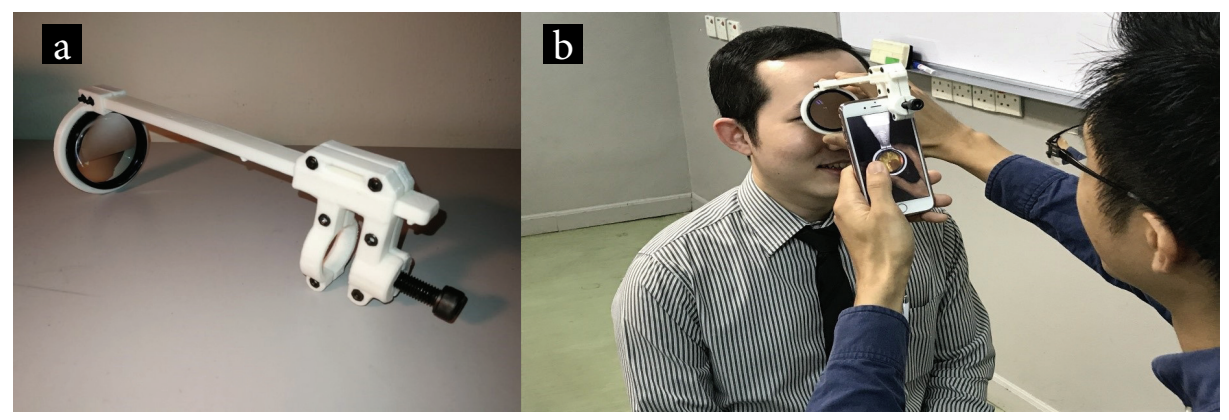

Fig. 1. (a) SRIA before attachment to mobile phone. (b) Using the SRIA for fundus photography. 


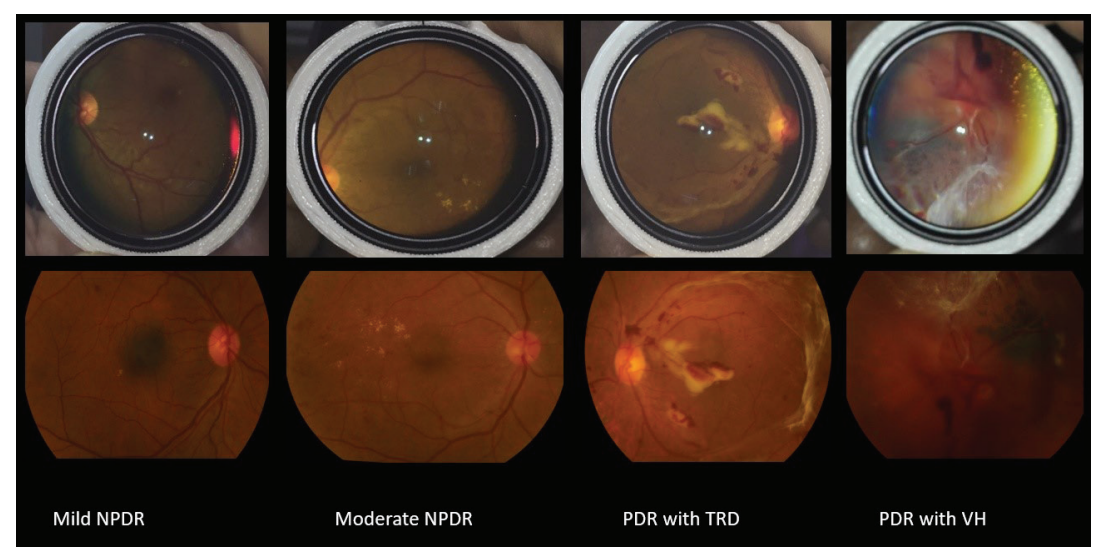

Fig. 2. Sample images from the SRIA (top) and corresponding images from the conventional fundus camera (bottom).

Subjects were seated comfortably to undergo both imaging modalities after their dilated slit-lamp examination. One researcher (YKG) conducted smartphone retinal imaging while trained technicians performed conventional fundus imaging. The average time taken for each patient was 10 minutes ( 5 minutes for SRIA and 5 minutes for conventional fundus imaging). Sample images from both imaging modalities are shown in Figure 2. Fundus images were recorded on the fundus camera and the iPhone 6 . After the data (image) collection stage was complete, all images were downloaded into a common folder and randomized in their order. One grader (YKG) who was blinded to the patients' clinical details graded them according to the EDTRS classification.

Before the actual study, inter-operator reliability between two graders (an ophthalmology trainee (YKG) and a consultant ophthalmologist with more than five years of experience (AS) was analysed using Cohen's Kappa statistics to determine the reliability of a single grader in evaluating the images from both cameras in this study. There was a substantial amount of agreement shown in the results, with a Kappa value of 0.748 (95\% Cl: 0.606 to $0.877, p<0.001)$ for DR and 0.960 (95\% Cl: 0.863 to $1.000, p<0.001$ ) for clinically significant macula oedema (CSME).

A sample size calculation was performed before the start of the study. In a test for agreement between the two modalities using the Kappa statistic, a sample size of 86 subjects would achieve $80.0 \%$ power to detect a true Kappa value of 0.60 in a test of $\mathrm{H}_{0}$ : Kappa $=0.78 v s . \mathrm{H}_{1}$ : Kappa $\neq 0.78$ when there are six categories with frequencies equal to $0.48,0.25,0.14,0.08,0.04$, and 0.01 . This power calculation was based on a significance level of 0.05 .

Statistical analysis was done using SPSS version 24.0. The verification of the SRIA using the Topcon conventional fundus camera as the standard was done applying Cohen's Kappa agreement statistics. Agreement was assessed for detecting DR as 
well as differentiating and grading DR severity. The level of agreement was based on that suggested by Landis and Koch. ${ }^{20}$ Sensitivity and specificity for the SRIA in detecting DR were also determined.

\section{Results}

A total of 284 eyes from 142 diabetic patients were enrolled into this study, which ran between June and December 2017. Three images were ungradable with the SRIA while six images were ungradable with the Topcon fundus camera because of cataracts and small pupils. The total percentage of non-proliferative diabetic retinopathy (NPDR) detected was $53.4 \%$ with the conventional fundus camera and $53.7 \%$ with the SRIA. Proliferative diabetic retinopathy (PDR) was detected in 57 cases (19.5\%) with the conventional fundus camera and 51 cases $(18.1 \%)$ with the SRIA. CSME was detected in $59(20.8 \%)$ cases with the SRIA while $74(26.1 \%)$ cases were detected using the conventional fundus camera. The agreement between the two cameras for CSME was 0.590 (95\% Cl: 0.470 to $0.701, p<0.001)$.

Table 1 reveals the DR severity according to each grade of DR. Kappa agreement between the SRIA and Topcon conventional fundus camera in detecting individual DR stages was 0.648 (95\% Cl: 0.584 to $0.713, p<0.001)$. Table 2 lists DR after clustering categories into no DR and mild NPDR, moderate and severe NPDR, and PDR. Kappa agreement between SRIA and Topcon conventional fundus camera after this clustering stood at 0.710 ( $95 \% \mathrm{Cl}: 0.634$ to $0.776, p<0.001)$. Table 3 categorises the severity into no DR, any NPDR, and PDR. The rate of agreement between the SRIA and Topcon conventional fundus camera for this clustering was 0.752 (95\% Cl: 0.654 to $0.834, p<0.001$ ). In general, our data showed that agreement improved when there was less sub-classification of DR grades. Finally, Table 4 lists the sensitivity and specificity of the SRIA according to the same grades of DR as in Table 3.

\section{Discussion}

In this study, we compared the grading of DR between SRIA and conventional fundus camera images. We found a substantial agreement when DR was classified into the various ETDRS stages. The measure of agreement increased when DR grades were clustered into no DR and mild NPDR, moderate and severe NPDR, and PDR. The best agreement was obtained when differentiating between no DR, NPDR, and PDR.

In a study reported by Russo et al. using their D-eye device and comparing it with dilated slit lamp retinal examination, they showed a substantial agreement with a Kappa value of $0.78 .{ }^{16}$ Another study by Rajalakshmi et al. showed a Kappa value of up to 0.90 for detecting any DR using their 'fundus on phone' camera and comparing it with mydriatic seven-field digital retinal colour photography. ${ }^{17}$ Our 


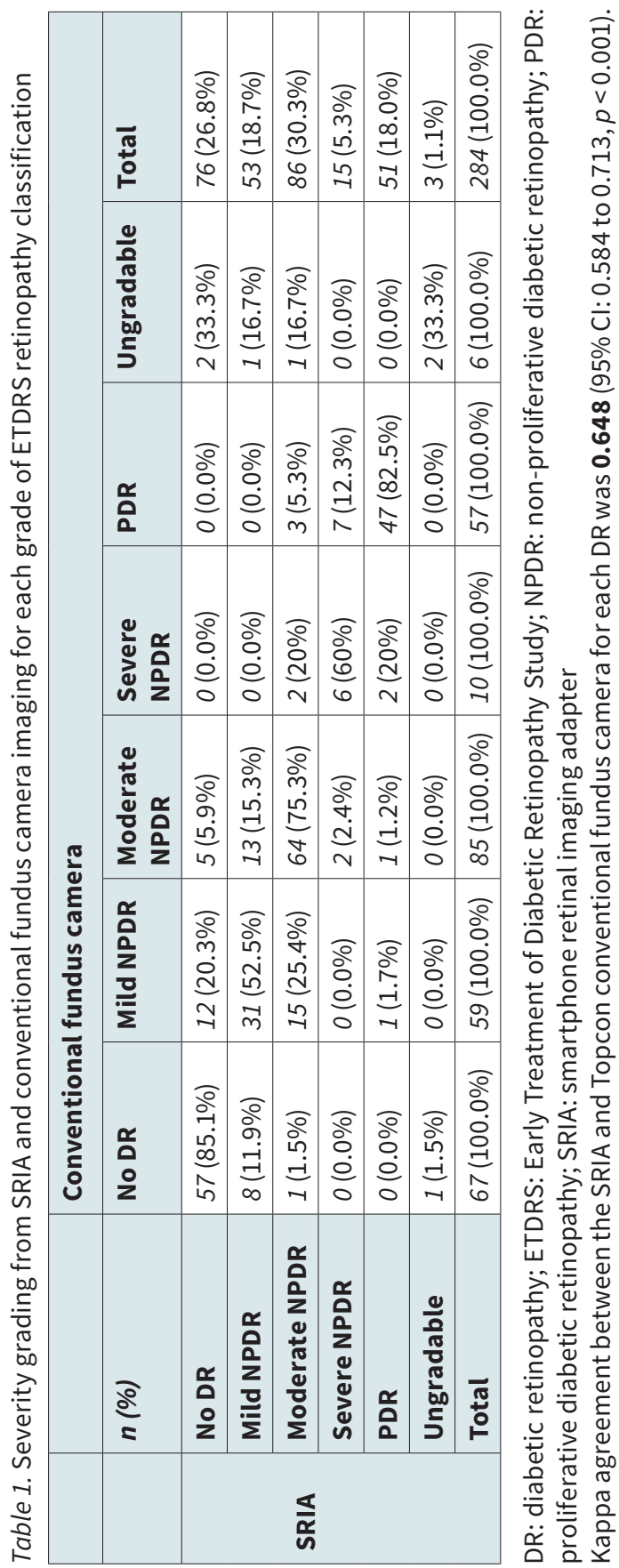


+
4
4
$\frac{1}{0}$
$\frac{1}{0}$
을

옴

읕

온

뜸

읃

올

든

㐫

$\frac{5}{\frac{1}{3}}$

묻

ס

हᄐ

ปั)

$\frac{1}{2}$

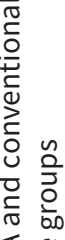

在

$\sqrt{\pi}$

ह 듀

은

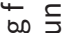

苋

कू

긍

숭

¿

n

$\sim \underset{0}{2}$

ํํㄴ

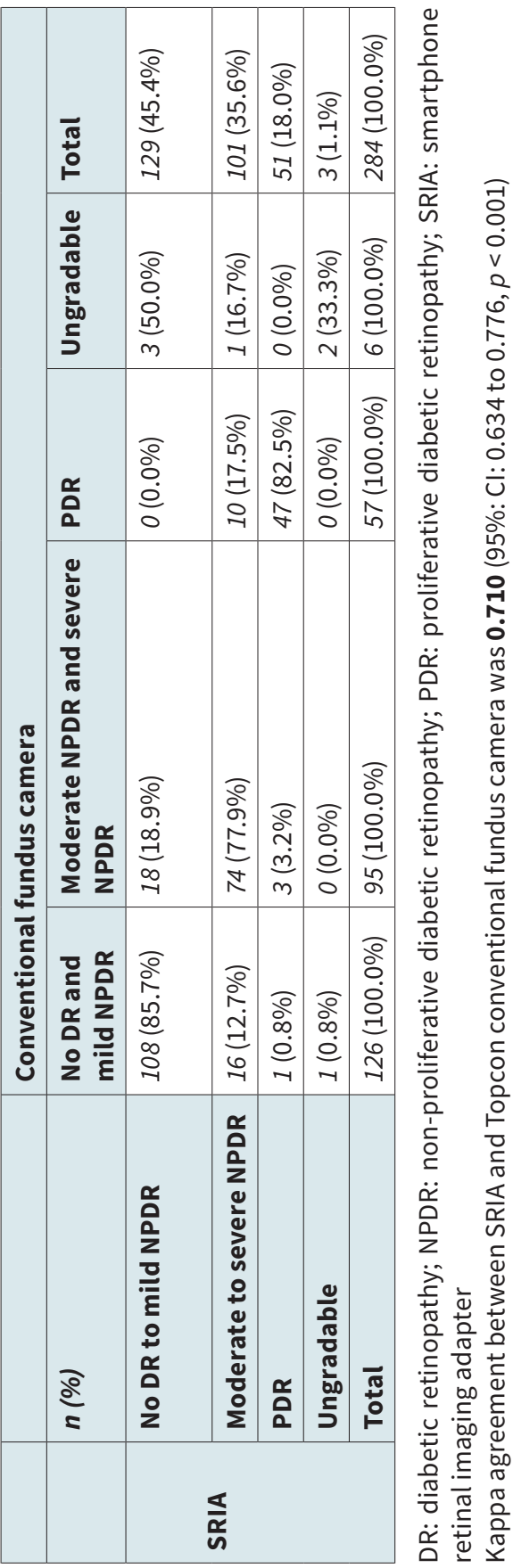




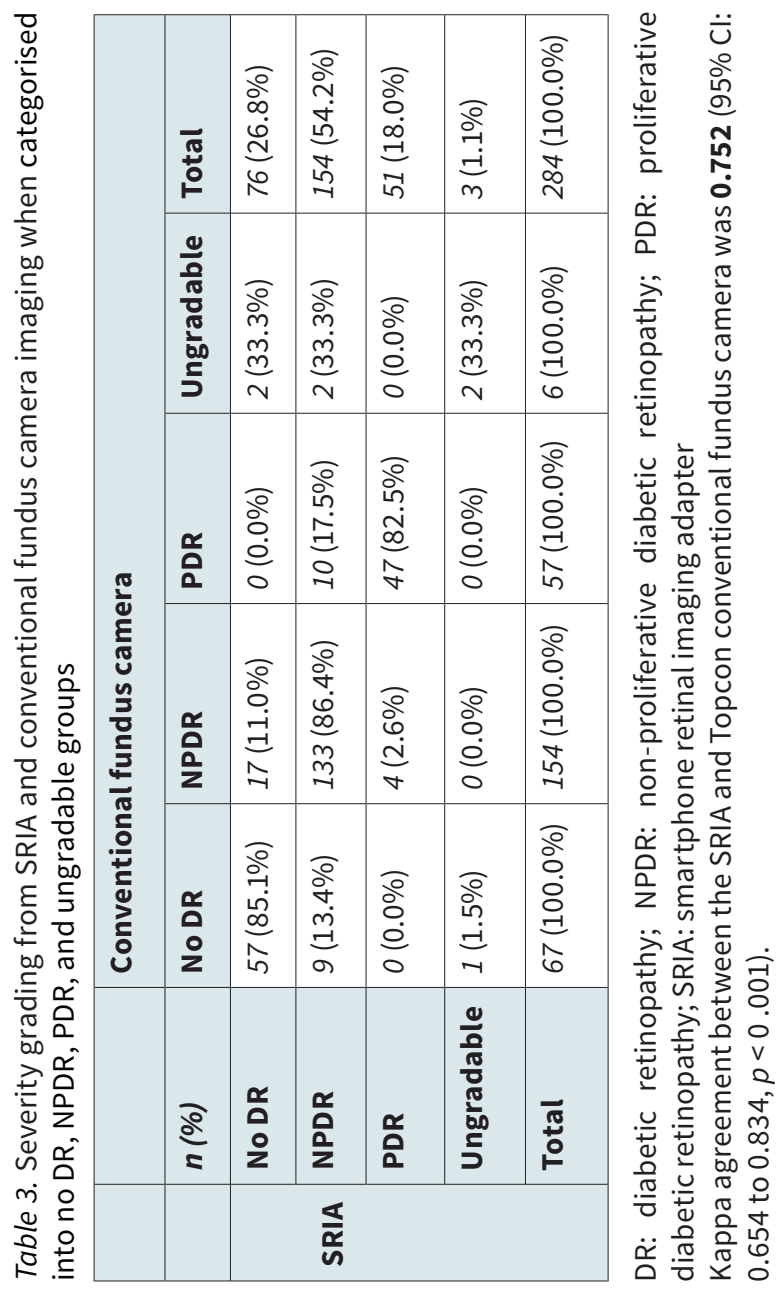




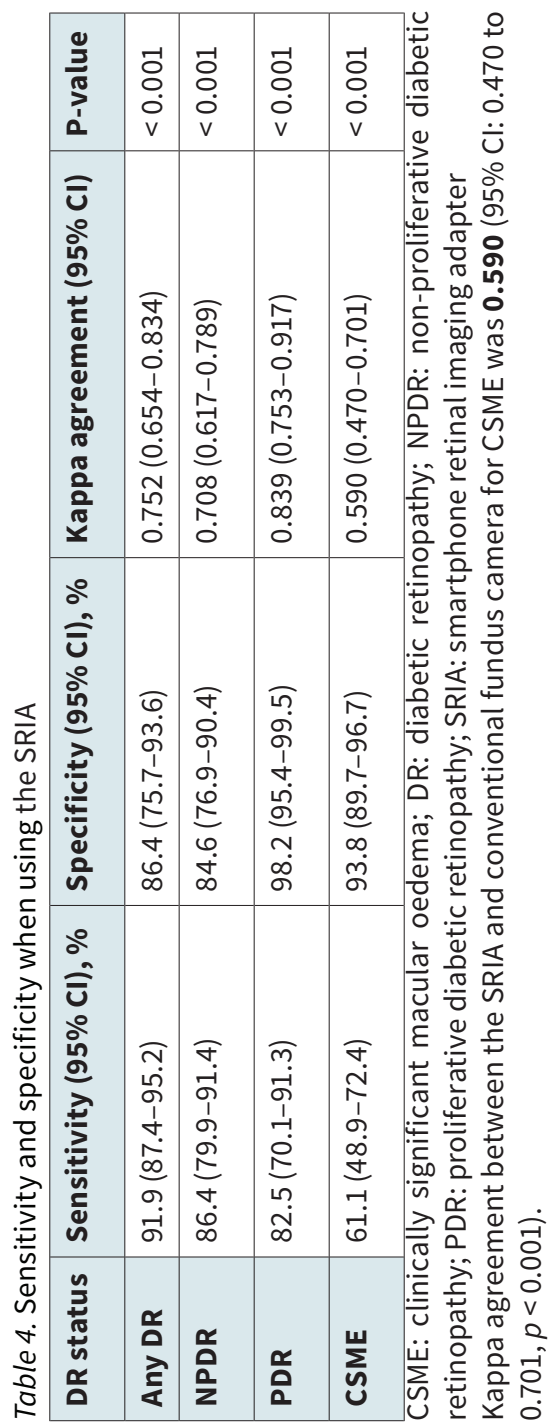


study of the SRIA displayed an agreement of 0.75 for detecting either no DR, NPDR, or PDR. Kappa agreement for detecting CSME in the same studies by Russo et al. and Rajalakshmi et al. were similar at 0.79, while our study had a lower agreement of 0.59 . One possible reason as to why our study performed worse than Russo et al. and Rajalakshmi et al. in this aspect is the lack of optical magnification in our device. For example, Russo et al. had a significantly higher magnification (similar to that of direct ophthalmoscopy) while using the video mode to compensate for the narrow $20^{\circ}$ field of view. Rajalakshmi et al. had a $12 x$ optical magnification built into their imaging system. However, the advantage of our SRIA device is that it is self-assembled and therefore considerably much lower in cost.

The SRIA did comparatively well in sensitivity and specificity in detecting any DR (91.9\% and $86.4 \%)$. It showed especially high sensitivity and specificity in detecting PDR (82.5\% and 98.2\%) cases, which are usually sight-threatening. In comparison, it was slightly lower than the "fundus on phone" validation study done by Rajalakshmi et al. ${ }^{17}$ which reported sensitivity and specificity values of $92.7 \%$ and $98.4 \%$, respectively, in detecting any DR. Apart from having higher optical magnification, their study utilised annular illumination, which provides better image quality and thus better results. Our study relied on the native flashlight of the smartphone, which was neither annular nor sufficiently co-axial. Further development of the current device could incorporate the mentioned features for improvement in detection of DR.

The SRIA produced fewer hazy images than the conventional fundus camera; hence, the SRIA was able to grade images that would otherwise be ungradable on the conventional fundus camera. This was possibly due to better light penetration with the SRIA, similar to how fundus images are better under indirect biomicroscopy compared to slit-lamp biomicroscopy.

In general, images derived from the SRIA have substantial agreement with those from conventional fundus imaging. We believe that it is a viable alternative for screening in rural areas where fundus cameras are not readily accessible. At the moment, it can be used as a portable tool to determine the urgency of referrals to ophthalmologists. For example, no DR and mild NPDR patients can be seen again after 6-12 months, moderate NPDR or severe NPDR patients will demand an earlier consult, and PDR findings would require urgent/ immediate attention for appropriate management.

The safety profile of the iPhone's native LED flashlight using a $20 \mathrm{D}$ condensing lens to illuminate fundi has been investigated and described previously. ${ }^{21,22}$ The iPhone 6 used in this study had a weighted retinal irradiance of $1.4 \mathrm{~mW} / \mathrm{cm}^{2}(504$ times below the thermal limit), weighted foveal irradiance of $1.61 \mathrm{~mW} / \mathrm{cm}^{2}$ (438 times below the thermal hazard level), and weighted retinal radiant exposure of $56.26 \mathrm{~mJ} / \mathrm{cm}^{2}$ (177 times below the photochemical limit). ${ }^{21}$ Hence, the retinal exposure from the iPhone 6 was within the safety limits for ophthalmic instruments set by the International Organization for Standardization (ISO15004-2.2), which 
are at least one order of magnitude below the actual retinal damage threshold. ${ }^{21}$ Patients were also comfortable with the overall experience of undergoing fundus photography. Additionally, patient education on DR was easier after showing them their respective fundus images for a better understanding of their eye health. For the user, the overall experience was satisfying, and it was relatively quick to get satisfactory image acquisition after overcoming the initial learning curve. Acquisition time significantly reduced after the initial ten patients.

Several technical limitations were encountered during the course of this study. Both imaging systems were highly dependent on good lighting. We noticed that in patients with cataracts, reduced light entering the eye resulted in dark or blurry, and subsequently ungradable images. This may be a disadvantage in rural communities where there may be higher incidences of cataracts. Consequently, real-world results may vary from that of this study. Additionally, the flash unit on the iPhone 6 is not completely co-axial, which resulted in some images being dark, and also distracts the patient due to reflection and glare. A device with proper co-axial lighting may provide much brighter images and reduce the amount of reflection and glare. Finally, a more focused beam of light similar to indirect ophthalmoscopes may also enhance the resolution and overall quality of the images taken.

\section{Conclusion}

There was substantial agreement in grading DR severity between SRIA and conventional fundus camera imaging. The agreement between the two modalities was best when used to differentiate between no DR, NPDR, and PDR. Smartphone retinal imaging may be a relatively low-cost, ultra-portable, and comparable way of screening for DR in the community.

\section{References}

1. Williams GA, Scott IU, Haller JA, Maguire AM, Marcus D, McDonald HR. Single-field fundus photography for diabetic retinopathy screening: a report by the American Academy of Ophthalmology. Ophthalmology. 2004;111(5):1055-1062.

2. Murgatroyd $\mathrm{H}$, Ellingford A, Cox A, et al. Effect of mydriasis and different field strategies on digital image screening of diabetic eye disease. Br J Ophthalmol. 2004;88(7):920-924.

3. Ting DS, Tay-Kearney ML, Kanagasingam Y. Light and portable novel device for diabetic retinopathy screening. Clin Experiment Ophthalmol. 2012;40(1).

4. Vujosevic S, Benetti E, Massignan F, et al. Screening for diabetic retinopathy: 1 and 3 nonmydriatic 45-degree digital fundus photographs vs 7 standard Early Treatment Diabetic Retinopathy study fields. Am J Ophthalmol. 2009;148(1):111-118. 
5. Aptel F, Denis P, Rouberol F, Thivolet C. Screening of diabetic retinopathy: effect of field number and mydriasis on sensitivity and specificity of digital fundus photography. Diabetes Metab. 2008;34(3):290-293.

6. Ku JJ, Landers J, Henderson T, Craig JE. The reliability of single-field fundus photography in screening for diabetic retinopathy: the Central Australian Ocular Health Study. Med J Aust. 2013;198(2):9396.

7. Lin DY, Blumenkranz MS, Brothers RJ, Grosvenor DM. The sensitivity and specificity of single-field nonmydriatic monochromatic digital fundus photography with remote image interpretation for diabetic retinopathy screening: a comparison with ophthalmoscopy and standardized mydriatic color photography. Am J Ophthalmol. 2002;134(2):204-213.

8. Olson J, Strachan F, Hipwell J, et al. A comparative evaluation of digital imaging, retinal photography and optometrist examination in screening for diabetic retinopathy. Diabet Med. 2003;20(7):528-534.

9. Boucher MC, Gresset JA, Angioi K, Olivier S. Effectiveness and safety of screening for diabetic retinopathy with two nonmydriatic digital images compared with the seven standard stereoscopic photographic fields. Can J Ophthalmol. 2003;38(7):557-568.

10. Neubauer AS, Welge-Lüßen UC, Thiel MJ, et al. Tele-screening for diabetic retinopathy with the retinal thickness analyzer. Diabetes Care. 2003;26(10):2890-2897.

11. Jin K, Lu H, Su Z, Cheng C, Ye J, Qian D. Telemedicine screening of retinal diseases with a handheld portable non-mydriatic fundus camera. BMC Ophthalmol. 2017;17(1):89.

12. Zhang W, Nicholas P, Schuman SG, et al. Screening for diabetic retinopathy using a portable, noncontact, nonmydriatic handheld retinal camera. J Diabetes Sci Technol. 2017;11(1):128-134.

13. Myung D, Jais A, He L, Blumenkranz MS, Chang RT. 3D printed smartphone indirect lens adapter for rapid, high quality retinal imaging. J Mob Technol Med. 2014;3(1):9-15.

14. Haddock LJ, Kim DY, Mukai S. Simple, inexpensive technique for high-quality smartphone fundus photography in human and animal eyes. J Ophthalmol. 2013;2013.

15. Dyaberi R, Bajantri Y, Khatib ZI, Hedge S, Khanna V. Smartphone Indirect Ophthalmoscopy: For Screening, and Documentation of the Ocular Fundus. J Vis. 2015;1(1):13.

16. Russo A, Morescalchi F, Costagliola C, Delcassi L, Semeraro F. Comparison of smartphone ophthalmoscopy with slit-lamp biomicroscopy for grading diabetic retinopathy. Am J Ophthalmol 2015;159(2):360-364.e1.

17. Rajalakshmi R, Arulmalar S, Usha M, et al. Validation of Smartphone Based Retinal Photography for Diabetic Retinopathy Screening. PloS One. 2015;10(9):e0138285.

18. Hong SC. 3D printable retinal imaging adapter for smartphones could go global. Graefes Arch Clin Exp Ophthalmol. 2015;253(10):1831-1833.

19. Hong S, O’Keeffe B, Wilson G. A Low Cost Integrated Retinal-Imaging System for Smartphone. J Med Diagn Meth. 2015;4(180):2.

20. Landis JR, Koch GG. An application of hierarchical kappa-type statistics in the assessment of majority agreement among multiple observers. Biometrics. 1977:363-74.

21. Hong SC, Wynn-Williams G, Wilson G. Safety of iPhone retinal photography. J Med Eng Technol. 2017;41(3):165-169.

22. Kim DY, Delori F, Mukai S. Smartphone photography safety. Ophthalmology. 2012;119(10):2200-2201. 